\title{
IMPLEMENTATION OF SCHOOL BASED MANAGEMENT IN TAMBILUNG ELEMENTARY SCHOOL
}

\author{
Nita Karmila ${ }^{\left.a^{*}\right)}$, Ade Wijaya ${ }^{a)}$ \\ ${ }^{a)}$ Universitas Pakuan, Bogor, Indonesia \\ ${ }^{*}$ Corresponding Author: nitakarmila2015@gmail.com
}

Article history: received 14 February 2020; revised 19 February 2020; accepted 23 February 2020

\begin{abstract}
This research aims to determine the extent of the successful implementation of school-based management in Tambilung Elementary School which is one of the small schools in Bogor Regency. This research is a descriptive qualitative research that provides in-depth explanations of data and information related to the implementation of school-based management in terms of three core components namely 1) School Management, 2) Active, Creative and Enjoyable Learning, and 3) Community Participation. From the results of the study it can be concluded that the implementation of school-based management in Tambilung Elementary School has only reached $83.62 \%$ which, if elaborated, the success of each component, namely: the school management component $85.89 \%$, the learning activity component amounted to $76.19 \%$ and the component of community participation in the implementation of schoolbased management is $88.80 \%$.
\end{abstract}

Keywords: school-based management

\section{INTRODUCTION}

Education has an important role in increasing the success of a nation. A nation that has good education Becomes an advanced nation in civilization, science and technology, social economy, and culture. One of the problems of education is the need for improvement and improvement of educational program material so that it can be adjusted to the increase for the sake of labor improvement and recovery of community change. The still low quality of education at every level of education at primary and secondary levels at the level of education in the country of Indonesia. Education management which was originally carried out centrally presents a variety of educational human resources and is considered as one of the causes of the low quality of education in Indonesia. The existence of decision making that is focused on the central government is the reason for the decline in creativity and innovation carried out in schools as implementing the policy. This limitation in space is one of the triggers for the low quality of education. The centralization of education gives the impression that authoritarian schools only require to improve the resources of the central government without providing the available resources in schools to the maximum extent possible to develop and improve the quality of education.

The centralization policy that has triggered low education has now been resolved with the change of the centralized policy to decentralized education which is an educational model that makes schools a decision-making process and one that supports the improvement of the quality of education and human resources that help professionalism of teachers who help this is troubled by various both regional and international parties. School based management is one of the solutions offered to improve the quality of education in Indonesia. The role of supervision is also one of the dominant aspects in evaluating the effectiveness of management in schools [1].

Based on the above thinking, it is necessary to conduct research on the implementation of school-based management in terms of three main components namely school management, learning activities and community participation in running school-based management. The formulation of the problem 1 . How is school management going on at Tambilung Elementary School in Bogor Regency? 2. How are active, creative, and fun learning activities taking place at Tambilung Elementary School, Bogor Regency? 3. What is the role of the community in implementing school-based management in Tambilung Elementary School, Bogor Regency?

School-based management is understood as a management process based on or prioritizing "policies" that are born from the implementation at the school unit level by taking into account the local potential that allows for national development [2]. School Based Management can be interpreted as the use of resources that are relevant to the school itself in teaching and learning [3]. In addition, Fatah [4] explained that School-Based Quality Management is a political approach that aims to redesign school management by giving power to school principals and increasing community participation in performance improvement efforts that include teachers, students, school committees, parents of students and Public. In line with the theory, Mulyasa [5] provided an explanation that School-Based Quality Management is a manifestation of more and more adequate education reform for students. Autonomy in management is a potential for schools to improve staff performance, offer direct participation in related groups, and increase public understanding of education.

Moradi [6] explained that school-based management refers to increasing the involvement of parents, students, 
teachers, officials, principals, and beneficiary groups from local communities and organizations that can increase the independence, responsibility and accountability of schools. As a result, key characteristics of school-based management can be anticipated to improve student academic achievement and other school outcomes because this local community claims closer monitoring of school staff, better student assessment, a closer match between school requirements and policies, and more again the effective use of resources. Research findings show that, for the implementation of school-based management, indicators such as management of the education system, curriculum, budget, educational content, the role of school principals, teachers, educators, students and other factors in Iran must be reconsidered.

According to Botha [7] there are two clear schools of thought on the issue of school-based management namely one school sees school-based management as a positive and successful vehicle for school improvement. Others argue that this has succeeded in improving schools. The principal's leadership role is widely regarded as a major factor that contributes to the successful relationship between schoolbased management and school improvement and is therefore an important dimension of successful school-based management. In line with Botha, Lazwardi [8] argues that the Implementation of School Based Management (SBM) is basically giving greater autonomy to schools with the ultimate goal of improving the quality of educational implementation outcomes so that they can produce tangible achievements through established managerial processes. School based management is the granting of broad autonomy at the level of the education unit in order to be able to manage resources and sources of funds and allocate them according to the level of need. The aim of school-based management is to improve the efficiency of the quality of education with independence and flexibility in managing existing resources. Components in school-based management include curriculum management and teaching programs, teaching staff management, student management, financial management and financing, facility management and educational infrastructure, public relations management and special service management.

From some of the above theories it can be defined that school-based management is an education management that gives more autonomy to schools to utilize the available resources optimally by involving the participation and support of various parties aimed at improving the quality of education.

\section{RESEARCH METHODS}

In general, this study aims to determine the extent of the successful implementation of school-based management in Tambilung Elementary School which is one of the small schools in Bogor Regency. This research is a descriptive qualitative research that will provide in-depth explanations of data and information related to the implementation of school-based management in terms of three core components namely 1) School Management, 2) Active, Creative and Enjoyable Learning, and 3) Community Participation.

The data source in this study is one headmaster with the status of a Civil Servant (PNS), a PNS teacher, one honorarium teacher and one student's parent. Data collection techniques were carried out by in-depth interviews, observation and documentation analysis. Data validation is done by triangulation and member check.

\section{RESULTS AND DISCUSSION}

In accordance with the predetermined problem formulation, this study will explain in detail related to the implementation of school-based management in terms of the school management component, active learning, creative and fun as well as from community participation.

Tambilung Elementary School is one of the small schools in Kp. Kadupugur, Ds. Mekarjaya, Kec. Rumpin Kab. Bogor. It is led by a PNS school principal, and has only five teachers consisting of one PNS teacher and four honorarium teachers and consisting of 110 students spread over six groups. Judging from the appropriateness of the teaching staff, there is a shortage of teaching staff so that one teacher is forced to concurrently manage two classes, namely first and second grade teachers.

School management is one of the important components that is a measure of success or failure of the education process. This relates to the role of the principal and teachers in managing each element that will support the success of education. In school management, vision and mission are the initial foundation to move on to further activities. Vision and mission must be made correctly so that it can be understood and implemented to the maximum by all school residents. Tambilung Elementary School already has a vision and mission compiled together by stakeholders both the school principal, teachers and school committee. The preparation of the vision and mission was followed by socialization so that all school members understood the outline of the vision and mission of the school that had been made. However, the obstacle to this vision and mission can only be accessed limitedly. This means that due to the weaknesses of schools that have not used other media than conventional so that only certain people who know the vision and mission. In terms of the facilities and infrastructure component, Tambilung Elementary School already has enough classes to carry out learning activities starting from the first grade to the sixth grade and has other complementary facilities. But Tambilung Elementary School does not yet have a library so it is difficult to facilitate reading literacy spaces for students. In addition, the lack of involvement of school residents in decision-making tends to be a lack of participative school residents to contribute to improving the quality of schools. In addition, there is still a limited increase in the professional abilities of principals so that schools are categorized as still minimal to pursue the rapid advancement of science and technology, especially in terms of school management. If the results of the interviews with the three speakers are presented in the form of a 
percentage then only $85 \%$ of school management has been well organized, so it needs to continue to improve to reach $100 \%$.

The learning activities component starts with a semester program and a lesson plan (RPP). The results showed that all teachers in Tambilung Elementary School were able to make lesson plans well. This is evidenced by the documentation that can be accounted for. However, only some teachers have implemented modern learning models and methods such as interactive media, learning models and teaching materials that are relevant to the times. The rest are teachers who still use conventional media so that this causes less interest in students participating in learning. On the other hand there are still limited school facilities that support successful learning. Among them the incomplete of books that support learning activities have not been fulfilled. If interpreted as a number, only $76 \%$ of learning activities have been carried out well. The rest needs to continue to improve in order to be able to reach $100 \%$.

Another thing that supports the successful implementation of school-based management, community participation is also very important, because the responsibility of education is not just the responsibility of the school, but there needs to be support from the community in this case the parents guardians, committees and other communities. The role of the school committee is very important as a bridge between the school and the community. At Tambilung Elementary School a school committee has been formed which functions as a support, consideration, control and mediator between the school and the parents of students and the wider community. The committee is chosen by the school principal and teacher. All administrators have understood the main tasks and functions of each. All committee programs are prepared by the committee chairman and the school principal. However, the implementation of the committee's program has only reached $50-74 \%$. The existence of the committee bridges communication between the school and the community so that it also makes it easier to assist in organizing school activities whose responsibilities are arranged at the end of each year. In this case the community's participation has reached $88.88 \%$ in the implementation of school-based management.

Of the three core components in the implementation of school-based management in Tambilung Elementary School, the implementation of school-based management has only been carried out $83.62 \%$.

\section{CONCLUSION}

From the results of the study it can be concluded that the implementation of school-based management in Tambilung Elementary School has only reached $83.62 \%$ which, if elaborated, the success of each component, namely: the school management component $85.89 \%$, the learning activity component amounted to $76.19 \%$ and the component of community participation in the implementation of schoolbased management is $88.80 \%$. This needs to be continuously improved so that the implementation of school-based management reaches $100 \%$ so that it will bring better changes to the progress of education in Tambilung Elementary School.

\section{REFERENCES}

[1] Y. Suchyadi, Nurjanah, and N. Karmila, Supervisi Pendidikan: Strategi Meningkatkan Profesionalisme Guru. Bogor: PGSD Universitas Pakuan, 2020.

[2] Kisbiyanto. Manajemen Sekolah. Mahameru: Yogyakarta. 2012.

[3] Andi Rasyid Pananrangi. Manajemen Pendidikan. Celebes Media Perkasa: Yogyakarta. 2017

[4] Nanang Fatah. Konsep Manajemen Berbasis Sekolah dan Dewan Sekolah. Pustaka Qurani: Bandung. 2016.

[5] E. Mulyasa. Manajemen Berbasis Sekolah Konsep Strategi dan Implementasi. Remaja Rosdakarya: Bandung. 2002.

[6] Saeid Moradia, Sufean Bin Hussinb , Nader Barzegarc. 2012. School-Based Management (SBM), Opportunity or Threat (Education systems of Iran). Procedia - Social and Behavioral Sciences 69 ( 2012 ) $2143-2150$.

[7] Nico Botha. 2006. Leadership in school-based management: a case study in selected schools. South African Journal of Education. Vol 26(3)341-353

[8] Dedi Lazwardi. 2018. Implementation Of SchoolBased Management. Al-Idarah: Jurnal Kependidikan Islam VIII (I) 2018. 